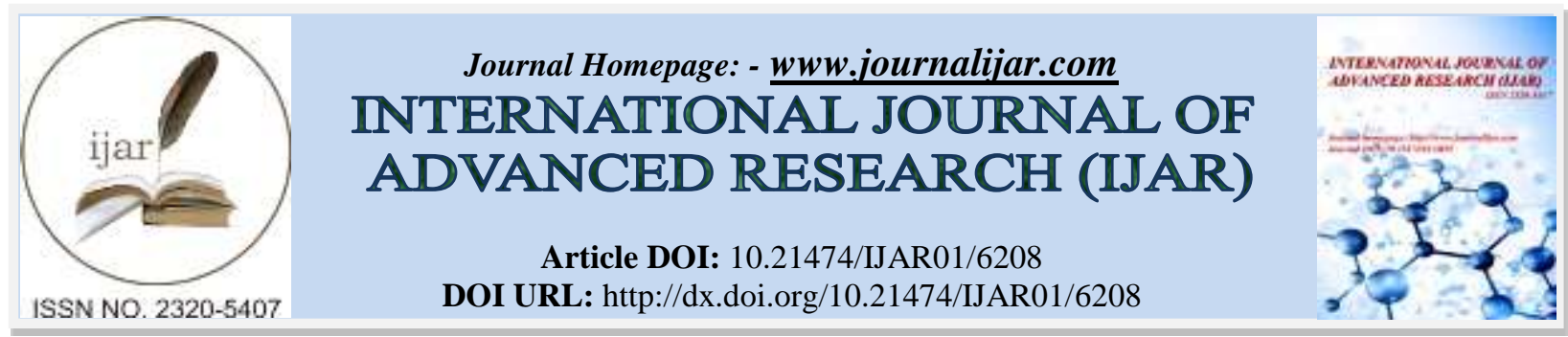

RESEARCH ARTICLE

\title{
STUDY ON ANTIBACTERIAL ACTIVITY OF BEE VENOM.
}

\section{Yeon Jo Ha ${ }^{1}$, Chi Won Noh $^{2}$, Woo Young Bang ${ }^{3}$, Sam Woong Kim ${ }^{1, \dagger}$ and Sang Wan Gal ${ }^{1}$.}

1. Department of Pharmaceutical Engineering, Gyeongnam National University of Science and Technology.

2. Gyeongsangnam-do Agricultural Research \& Extension Services, Jinju, 52733, South Korea.

3. National Institute of Biological Resources (NIBR), Environmental Research Complex, Incheon 22689, South Korea.

\section{Manuscript Info}

Manuscript History

Received: 04 November 2017

Final Accepted: 06 December 2017

Published: January 2018

Keywords:-

AMPs, antimicrobial activity, bee venom,

ghost vaccine, MIC, Salmonella

Typhimurium.

\begin{abstract}
The purpose of this study was to investigate the antimicrobial activity against Salmonella infection which causes intestinal diseases from bee venom which is one of the social insects, and to find a way which use ghost vaccine. The minimum inhibitory concentration (MIC) of bee venom against Salmonella Typhimurium $\chi 3339$ was $101.81 \mathrm{ug} / \mathrm{ml}$. Based on the result of MIC, the antimicrobial activity according to amount of the cells showed strong activities below $10^{6} \mathrm{CFU} / \mathrm{ml}$, but exhibited no and low activity at $10^{8}$ and $10^{7} \mathrm{CFU} / \mathrm{ml}$, respectively. In addition, the antimicrobial activity assay according to the cultural temperature showed the strongest activity at $37^{\circ} \mathrm{C}$. The thermal stability of bee venom appeared to be very stable at temperatures below $60^{\circ} \mathrm{C}$, but gradually decreased at more than $60^{\circ} \mathrm{C}$. The protease inhibitor mixture was shown to greatly enhance the antimicrobial activity of bee venom. Since most of the activity is lost due to the treatment with Proteinase $\mathrm{K}$, it is estimated that the antimicrobial activity of bee venom is induced by peptides. Therefore, we suggest that bee venom can be used as an antimicrobial agent for ghost vaccine production.
\end{abstract}

Copy Right, IJAR, 2018,. All rights reserved.

\section{Introduction:-}

Bee venom is a colorless transparent and viscous liquid to maintain strong aromatic bitter taste, and an off-white or yellowish white mass or powder in dry state. The specific gravity of the bee venom solution is 1.13 and the acidity is in the range of $5.2 \sim$ 5.5. Bee venom is easy to dissolve in water and acids, but hardly soluble in alcohol. The bee venom solution loses $70 \%$ of its liquid weight by quickly drying when exposed to air at room temperature. Bee venom maintains its long-term activity in the frozen state, but tends to be easily destroyed by oxidizing substances (Koh, 1993; Kim, 1996).

Bee venom is composed of about 40 components, which consists of peptide components such as melittin, apamin, and mastcell degranulating (MCD) peptide, enzyme components such as phospholipase A2, hyauronidase, and acid phosphomonoester, and amine components such as histamine, dopamine, and noradrenaline (Chmielewska and Szczęsna, 2004; Kokot and Matysiak, 2009). Among them, melittin is a major component that accounts for about $50 \%$ of the dry bee venom, and it is known that it works very well in pain and inflammation (Piek, 1986; Curcio-Vonlanthen V et al., 1997). Melittin was first discovered as a hemolytic element in 1954, and observed by cell membrane activity during erythrocyte lysis in 1972 (Lee et al., 2000). Structurally, it consists of 26 amino acids, which strongly inhibits macrophage migration and synergizes with phospholipase A2 during hemolysis to increase mutual activity. In the enzyme action, it stimulates catecholamine and cortisone secretion by stimulating the pituitary and adrenal cortex system, induces an increase of serotonine in the hypothalamus, and has anti- 
inflammatory action via stabilization of the lysosomal membranes (Kwan et al., 2000; Lee, 2000). There are also dissolution, enzymes, pain induction, radiation-resistant action, and antibacterial action (An et al., 2010).

To date, many AMPs (antimicrobial peptides) have been obtained from nature, but the most promising candidates in recent years have been originated from poisonous animals such as snakes, scorpions, spiders, ants, wasps, bees, and centipede (Wang et al., 2016). Peptide toxins such as androtonin, parbutoporin, opistoporins, TstH, and vpAmp 1.0, which are derived from scorpion venom, show strong antimicrobial activity against Gram-positive bacteria, Gram-negative bacteria or fungi (Hetru et al., 2000; Powers and Hancock, 2003; Ramirez-Carreto et al., 2015; Machado et al., 2016). Cardiotoxin and crotamine of snake venom show strong activity against bacteria and fungi (Chen et al., 2011; Oguiura et al., 2011). In particular, bee and spider poisons yield AMPs more than 20,000 and 40,000 members, respectively (Wang et al., 2016).

In this study, the antimicrobial activity against Salmonella Typhimurium $\chi 3339$, a causative organism of Salmonella infection, was evaluated by the bee venom and examined for the possibility to apply the venom for preparation of ghost vaccine.

\section{Materials and Methods:-}

Bee venom and bacterial strain:-

The bee venom powder used in this study was purchased from Chung Jin Biotech Co., Ltd (South Korea), and applied as a concentration of $10 \mathrm{ug} / \mathrm{ul}$. The test strain was examined by Salmonella Typhimurium $\chi 3339$.

\section{Analysis of minimal inhibitory concentration (MIC):-}

MIC analysis of bee venom against Salmonella Typhimurium $\chi 3339$ was performed with a microtiter plate method. Bee venom powder was dissolved in an appropriate concentration $(10 \mu \mathrm{g} / \mu \mathrm{l})$ and used for antimicrobial activity analysis. The used strain was employed for MIC assay by adjusting the precultured broth to $10^{6} \mathrm{CFU} / \mathrm{ml}$ or an appropriate concentration. The concentrations of bee venom used in the analysis were $0,25,50,100$, and $250 \mu \mathrm{g} / \mathrm{ml}$. Each $200 \mu \mathrm{l}$ of the reaction solution was added into a microtiter plate, and the antimicrobial activity was observed after culturing at $37^{\circ} \mathrm{C}$ for $16 \mathrm{~h}$. The results were measured at $600 \mathrm{~nm}$ with an ELISA leader (Multiscan GO, Thermo Scientific Co. Ltd., Rochester, NY, USA).

Antibacterial activity of bee venom according to the amount of bacterial cells:-

The antimicrobial activity of Salmonella Typhimurium $\chi 3339$ for the amount of bacterial cells was assayed by a microtiter plate method. Concentration of bee venom according to MIC results obtained from $10^{6} \mathrm{CFU} / \mathrm{ml}$ were used for the subsequent analysis of antimicrobial activity. The used strains were employed for the evaluation depending on the amount of bacterial cells by adjusting the cultured broth at concentrations of $10^{8}, 10^{7}, 10^{6}, 10^{5}, 10^{4}$, and $10^{3} \mathrm{CFU} / \mathrm{ml}$. Each $200 \mu \mathrm{l}$ of the reaction solution was added into a microtiter plate, and the antimicrobial activity was observed after culturing at $37^{\circ} \mathrm{C}$ for $16 \mathrm{~h}$. The results were measured at $600 \mathrm{~nm}$ with an ELISA leader (Multiscan GO, Thermo Scientific Co. Ltd., Rochester, NY, USA).

\section{Analysis of antimicrobial activity for bee venom by temperature}

The antimicrobial activity of Salmonella Typhimurium $\chi 3339$ by temperature was assayed by microtiter plate method. The bee venom was used for the antimicrobial activity analysis according to the MIC result. The used strain was employed for MIC assays by adjusting the precultured broth to $10^{6} \mathrm{CFU} / \mathrm{ml}$ or an appropriate concentration. Each $200 \mu \mathrm{l}$ of the reaction solution was added into a microtiter plate, and the antimicrobial activity was observed after culturing at $37^{\circ} \mathrm{C}$ for $16 \mathrm{~h}$. The results were measured at $600 \mathrm{~nm}$ with an ELISA leader (Multiscan GO, Thermo Scientific Co. Ltd., Rochester, NY, USA).

\section{Evaluation of thermal stability for bee venom:-}

Analysis of the thermal stability of bee venom for Salmonella Typhimurium $\chi 3339$ was performed using a microtiter plate method. The bee venom was used for the antimicrobial activity analysis according to the MIC result. The used strain was employed for evaluation of thermal stability by adjusting the precultured broth to $10^{6} \mathrm{CFU} / \mathrm{ml}$ or an appropriate concentration. The bee venom used in the evaluation was examined after heating for 10 minutes at $0,30,40,50,60,70$, and $80^{\circ} \mathrm{C}$, respectively. Each $200 \mu \mathrm{l}$ of the reaction solution was added into a microtiter plate, and the antimicrobial activity was observed after culturing at $37^{\circ} \mathrm{C}$ for $16 \mathrm{~h}$. The results were measured at $600 \mathrm{~nm}$ with an ELISA leader (Multiscan GO, Thermo Scientific Co. Ltd., Rochester, NY, USA).

\section{Antibacterial activity of bee venom according to protease inhibitor mixture:-}

Antimicrobial activities of Salmonella Typhimurium $\chi 3339$ according to protease inhibitor mixture of bee venom were analyzed by microtiter plate method. The bee venom was used for the antimicrobial activity analysis according to the MIC result. The used strains were employed for evaluation of an effect for protease inhibitor mixture by adjusting the precultured broth to $10^{8} \mathrm{CFU} / \mathrm{ml}$ or an appropriate concentration. The protease inhibitor mixture used in the assay was Protease inhibitor P8465 (Sigma-Aldrich, Milwaukee, WI, USA) and the concentrations were $0,0.5,1,2,5$, and $10 \mu \mathrm{l}$. Each $200 \mu \mathrm{l}$ of the reaction solution was added into a microtiter plate, and the antimicrobial activity was observed after culturing at $37^{\circ} \mathrm{C}$ for $16 \mathrm{~h}$. The results were measured at 600 $\mathrm{nm}$ with an ELISA leader (Multiscan GO, Thermo Scientific Co. Ltd., Rochester, NY, USA). 
Analysis of antimicrobial activity of bee venom by simultaneous treatment with Proteinase K:-

The antimicrobial activities of Salmonella Typhimurium $\chi 3339$ by simultaneous treatment with Proteinase K of bee venom were analyzed by microtiter plate method. The used strain was employed for evaluation of an effect for protease by adjusting the precultured broth to $10^{6} \mathrm{CFU} / \mathrm{ml}$ or an appropriate concentration. Proteinase K (Sigma-Aldrich, Milwaukee, WI, USA) was used by $80 \mathrm{ug} / \mathrm{ml}$ concentration for the analysis. Each $200 \mu \mathrm{l}$ of the reaction solution was added into a microtiter plate, and the antimicrobial activity was observed after culturing at $37^{\circ} \mathrm{C}$ for $16 \mathrm{~h}$. The results were measured at $600 \mathrm{~nm}$ with an ELISA leader (Multiscan GO, Thermo Scientific Co. Ltd., Rochester, NY, USA). Proteinase K (Sigma-Aldrich, Milwaukee, WI, USA) was used by for the analysis.

\section{Results and Discussion:-}

\section{Antimicrobial activity against $S$. Typhimurium:-}

This study was done to evaluate the efficacy of commercially available bee venom through $S$. Typhimurium. It is known that the antibacterial activity of commercial bee venom is 20 to $40 \mathrm{ug} / \mathrm{ml}$ (Leandro et al., 2015). However, it was presumed that some activities were changed during addition of excipient and drying process in the process of powdering bee venom. As a result of this study with the purchased bee venom, the minimal inhibitory concentration (MIC) for $S$. Typhimurium $\chi 3339$ was observed by $101.8085 \mathrm{ug} / \mathrm{ml}$ (Fig. 1). This result is $2.5 \sim 5$ times lower than the previous research results. Therefore, it is judged that the excipient is mixed with the corresponding concentration or some activity is lost in the drying process.

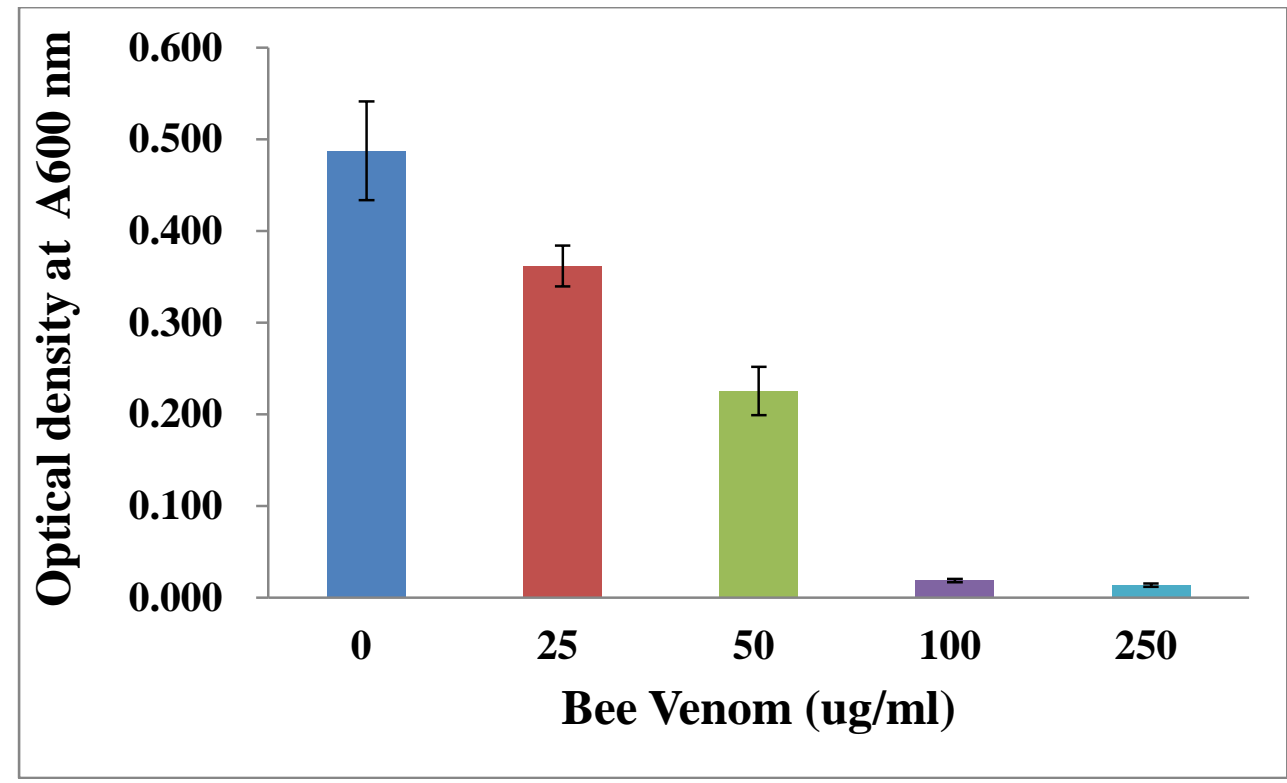

Fig. 1:- Evaluation of antibacterial activity for bee venom. Salmonella Typhimurium $\chi 3339$ strain was diluted to $10^{6} \mathrm{CFU} / \mathrm{ml}$ and applied for the study. Bee venom was used by concentration of $10 \mu \mathrm{g} / \mu \mathrm{l}$ and added at concentrations of $0,25,50,100$, and 250 $\mu \mathrm{g} / \mathrm{ml}$. X- and Y-axes indicate optical density at $600 \mathrm{~nm}$ and concentration of bee venom, respectively.

One of the purposes of this study is to produce Salmonella ghost vaccine with treatment of bee venom. Therefore, we investigated whether the bee venom activity is a good function in high population of the strain. The antimicrobial activity was evaluated by the amount of MIC value obtained from $10^{6} \mathrm{CFU} / \mathrm{ml}$ to investigate the antimicrobial activity against the high concentration of the bacterial mass. As shown in Fig. 2, higher activity was observed below $10^{6} \mathrm{CFU} / \mathrm{ml}$, whereas the activity was markedly lowered at $10^{7} \mathrm{CFU} / \mathrm{ml}$ and little activity at $10^{8} \mathrm{CFU} / \mathrm{ml}$. Therefore, it is suggested that a higher content of bee venom must be used in order to exhibit high antimicrobial activity at $10^{8} \mathrm{CFU} / \mathrm{ml}$. Although it is a disadvantage of using a high concentration of bee venom, it is assumed that bee venom powder employed in this study is a possibility of application as a raw material for production of ghost vaccine. 


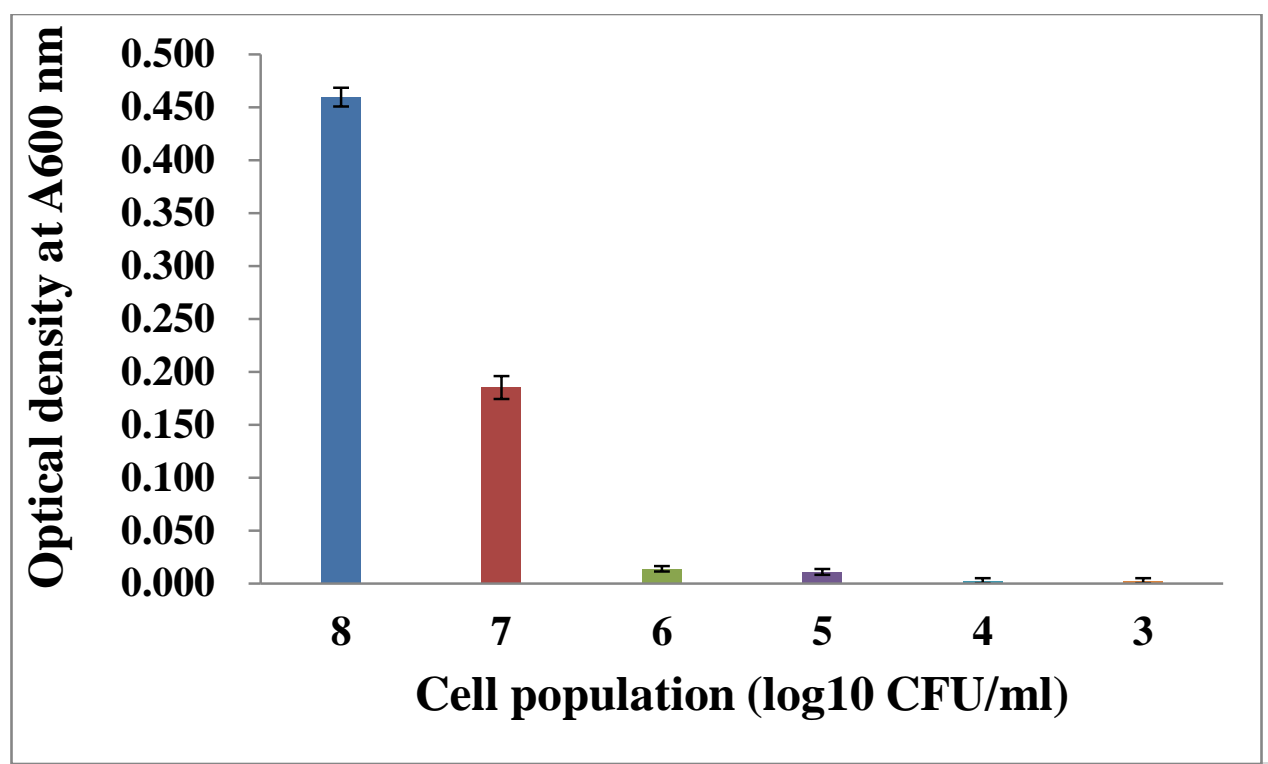

Fig. 2:- Evaluation of antimicrobial activity according to the amount of cells. Salmonella Typhimurium $\chi 3339$ strain was diluted to $10^{8}, 10^{7}, 10^{6}, 10^{5}, 10^{4}$, and $10^{3} \mathrm{CFU} / \mathrm{ml}$, respectively, and employed for the study. Bee venom was used as a stock at a concentration of $10 \mu \mathrm{g} / \mu \mathrm{l}$, and added at the concentration of the MIC of $10^{6} \mathrm{CFU} / \mathrm{ml}$. X- and Y-axes indicate optical density at $600 \mathrm{~nm}$ and amount of the cells, respectively.

Evaluation of thermal stability:-

To investigate the suitable temperature for bee venom to be used for ghost vaccination, we evaluated the antimicrobial activity according to each cultural temperature of $S$. Typhimurim. As shown in Fig. 3, high activity was observed at $25^{\circ} \mathrm{C}$ and $37^{\circ} \mathrm{C}$, but remarkably low activity was observed at $42^{\circ} \mathrm{C}$. Bee venom treated at $25^{\circ} \mathrm{C}$ showed high antimicrobial activity, but overall growth was significantly reduced. Therefore, it is suggested that treatment at $37^{\circ} \mathrm{C}$ was appropriate for ghost formation of $S$. Typhimurium.

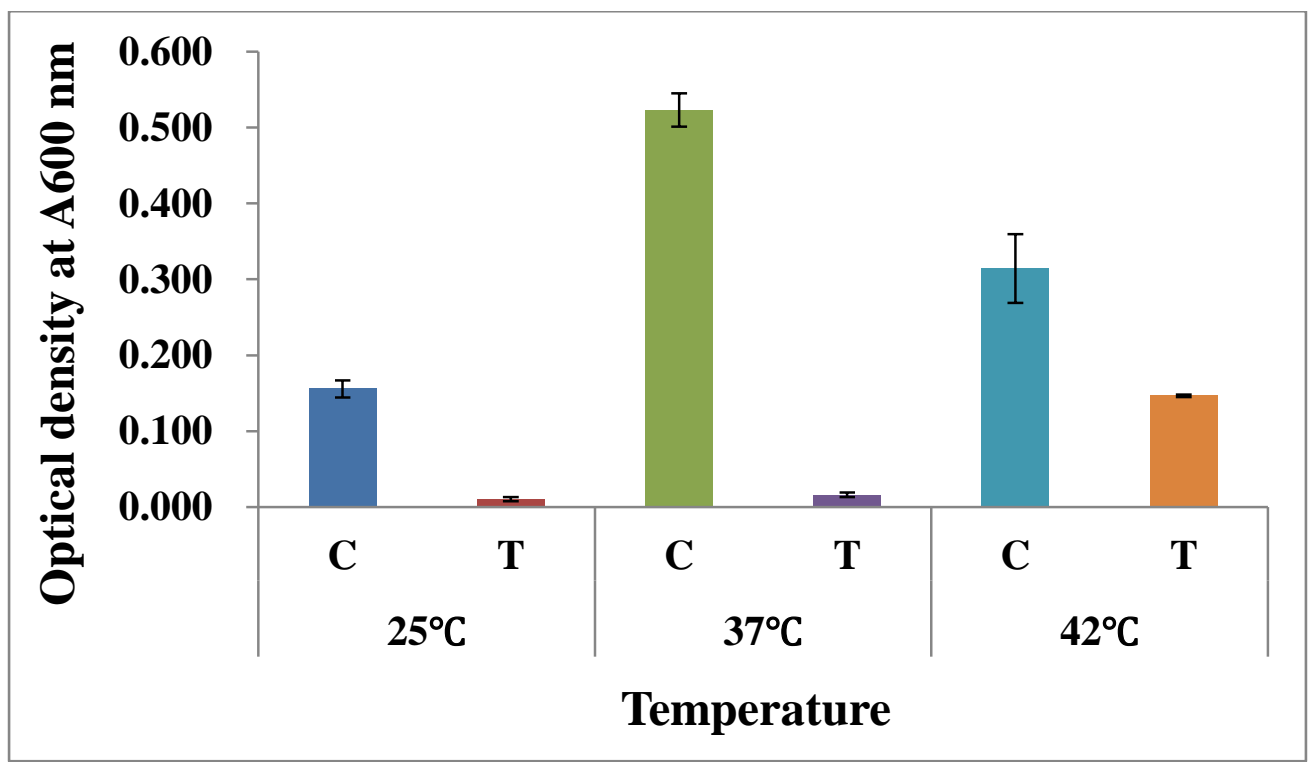

Fig. 3:- Examination of antimicrobial activity according to cultural temperature. Salmonella Typhimurium $\chi 3339$ strain was diluted to $10^{6} \mathrm{CFU} / \mathrm{ml}$ and applied for the study. Bee venom was used by concentration of $10 \mu \mathrm{g} / \mu \mathrm{l}$, and added at the concentration of the MIC of $10^{6} \mathrm{CFU} / \mathrm{ml}$. X- and Y-axes indicate optical density at $600 \mathrm{~nm}$ and cultural temperature, respectively. C; control without bee venom, T; treatment with bee venom.

In order to increase the possibility of commercial application, the used AMPs must have high thermal stability. Therefore, in this study, heat stability was evaluated at each temperature for 10 minutes. As shown in Fig. 4, the activity was remained by treatment 
at $0^{\circ} \mathrm{C}, 30^{\circ} \mathrm{C}, 40^{\circ} \mathrm{C}$, and $50^{\circ} \mathrm{C}$ for 10 minutes, but the activity was gradually decreased when the temperature was further increased. Therefore, it is presumed that most activity of the bee venom is retained when it is treated at a temperature of $60^{\circ} \mathrm{C}$ or lower in the processing process for powder.

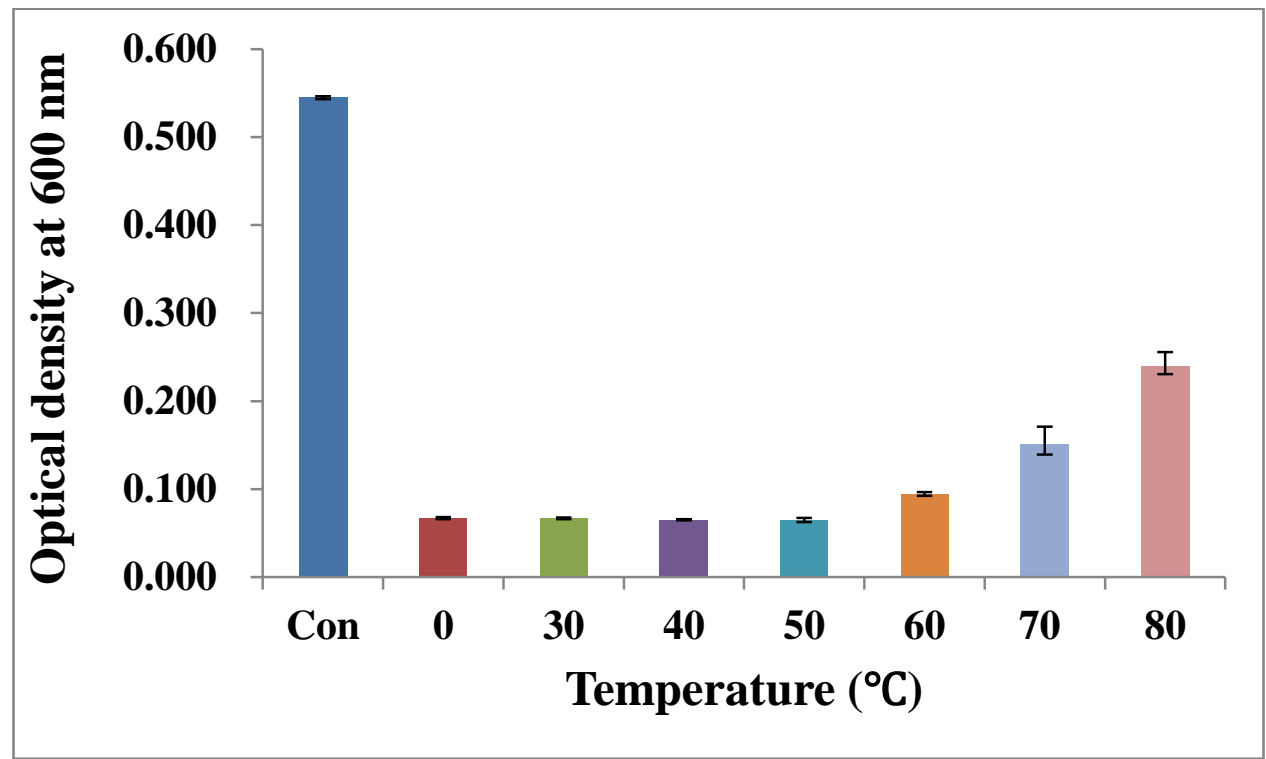

Fig. 4:- Evaluation of thermal stability of bee venom. Salmonella Typhimurium $\chi 3339$ strain was diluted to $10^{6} \mathrm{CFU} / \mathrm{ml}$ and applied for the study. Bee venom was used by concentration of $10 \mu \mathrm{g} / \mu \mathrm{l}$, and added at the concentration of the MIC of $10^{6}$ $\mathrm{CFU} / \mathrm{ml}$. Bee venom was added after heating for 10 minutes at $0 \sim 80^{\circ} \mathrm{C}$. X- and Y-axes indicate optical density at $600 \mathrm{~nm}$ and cultural temperature, respectively. Con; control without bee venom.

Analysis of association between antimicrobial activity and peptide:-

Treatment with high-concentration of Salmonella at MIC value of $10^{6} \mathrm{CFU} / \mathrm{ml}$ showed a tendency to significantly decrease activity at an amount of the cells higher than $10^{7} \mathrm{CFU} / \mathrm{ml}$ (Fig. 1). Therefore, to overcome these drawbacks, we analyzed the activity with a protease inhibitor mixture. It is well known that protease inhibitor plays a role in inhibiting the activity of protease in the cultural medium and correcting the MIC value (Ha et al., 2017).

Protease inhibitor mixture was added in each concentration to analyze its activity. As a result, the treatment with protease inhibitor mixture depending on concentration showed that the activity of the mixture was increased by $50 \%$ or more when $1 \mu l$ of the mixture was treated and increased to the maximum value at $2 \mu \mathrm{l}$ (Fig. 5). These results are consistent with the results of mastoparan V1 originated from a wasp venom toxin (Ha et al., 2017).

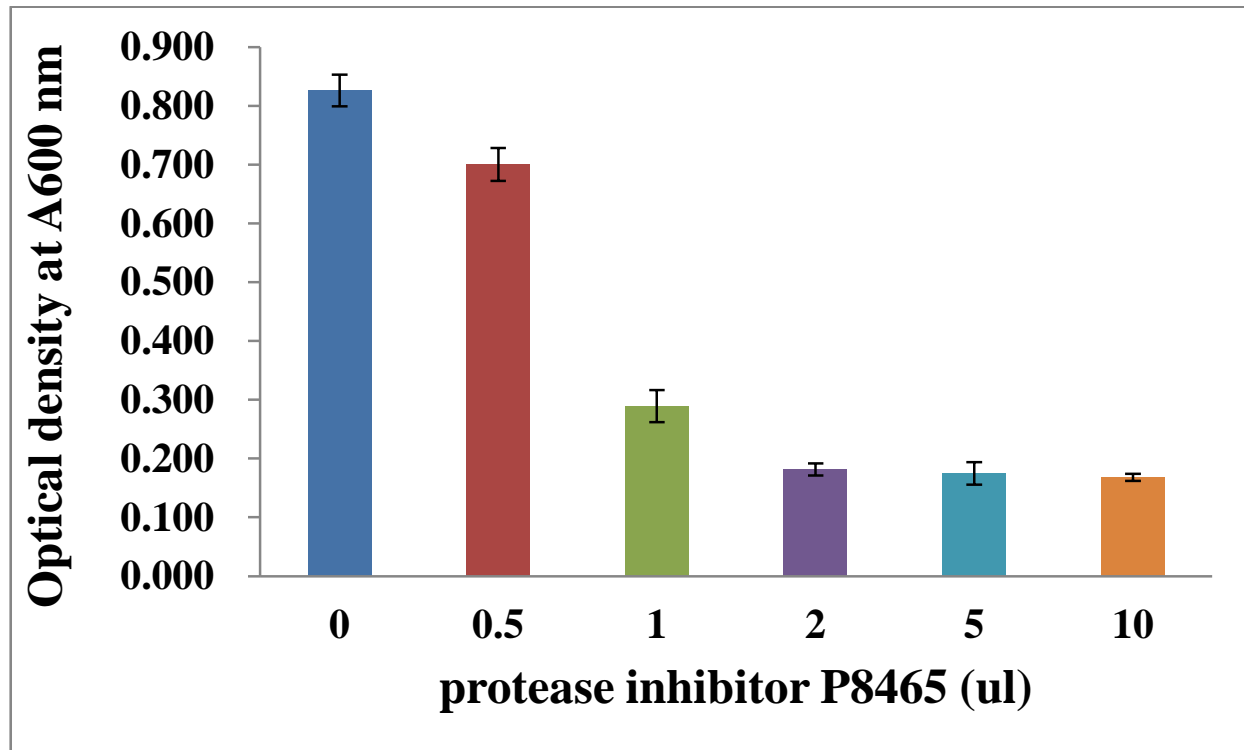


Fig. 5:- Examination of antimicrobial activity depending on concentration of protease inhibitor mixture. Salmonella Typhimurium $\chi 3339$ strain was diluted to $10^{8} \mathrm{CFU} / \mathrm{ml}$ and applied for the study. Bee venom was used by concentration of 10 $\mu \mathrm{g} / \mu \mathrm{l}$, and added at the concentration of the MIC of $10^{6} \mathrm{CFU} / \mathrm{ml}$. Protease inhibitor mixture was added in an amount of $0 \mu \mathrm{l}, 0.5$ $\mu \mathrm{l}, 1 \mu \mathrm{l}, 2 \mu \mathrm{l}, 5 \mu \mathrm{l}$, and $10 \mu \mathrm{l}$. X- and Y-axes indicate optical density at $600 \mathrm{~nm}$ and concentration of protease inhibitor mixture,

$$
\text { respectively. }
$$

We treated proteinase $\mathrm{K}$ in order to confirm that the antimicrobial activity of bee venom is derived from the peptide. As a result, high activity was observed when proteinase $\mathrm{K}$ was not treated, but proteinase $\mathrm{K}$ treatment showed low activity regardless of activation and inactivation states of proteinase K (Fig. 6). The MIC of melittin and phospholipase A2 were $4 \sim 40$ and $400 \mathrm{ug} / \mathrm{ml}$, respectively, whereas in the case of treatment at the same time, the MIC was $6 \sim 80 \mathrm{ug} / \mathrm{ml}$ (Leandro et al., 2015). Therefore, it is assumed that most of the antimicrobial activity of bee venom is derived from the peptide melittin and phospholipase A2.

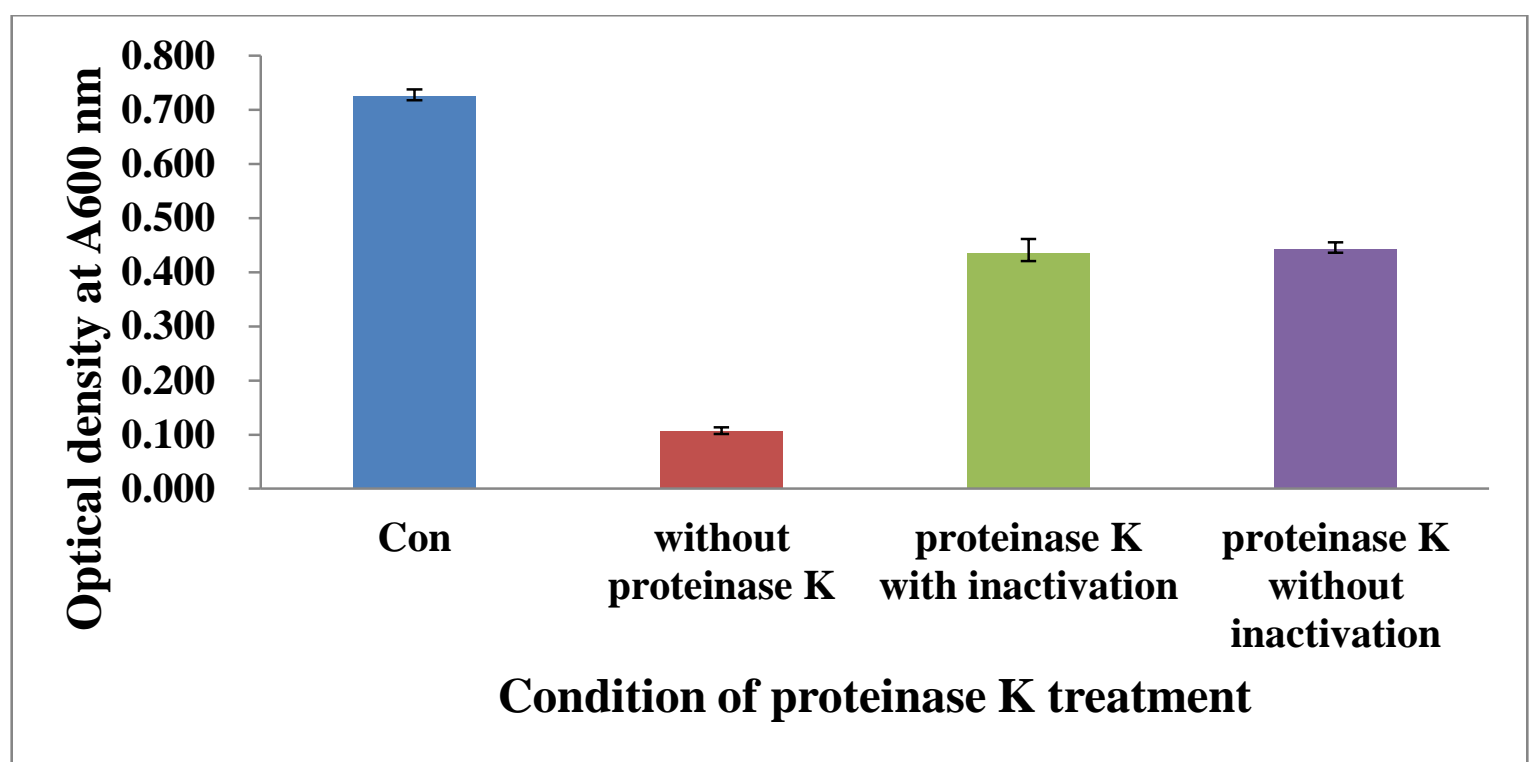

Fig. 6:- Analysis of antimicrobial activity according to simultaneous treatment with proteinase K. Salmonella Typhimurium $\chi 3339$ strain was diluted to $10^{6} \mathrm{CFU} / \mathrm{ml}$ and applied for the study. Bee venom was used by concentration of $10 \mu \mathrm{g} / \mu \mathrm{l}$, and added at the concentration of the MIC of $10^{6} \mathrm{CFU} / \mathrm{ml}$. X- and Y-axes indicate optical density at $600 \mathrm{~nm}$ and concentration of protease inhibitor mixture, respectively. Con; non treated.

In summary, these results indicate that bee venom purchased from the market is slightly lower than the general activity, but it can be used for the production of ghost vaccine when mixed with a protease inhibitor mixture. In addition, since it has a temperature stability up to $60^{\circ} \mathrm{C}$, it has been found that there is no problem in making the powder into industrial use.

\section{Acknowledgements:-}

This work was supported by Gyeongnam National University of Science and Technology Grant 2016.

\section{References:-}

1. An KW, Kim NY, Seo KY, Kim CG. 2010. Melittin content analysis of Korea and another country bee venom using HPLC. J. Apic. 25: 283-290.

2. Band VI, Weiss DS. 2014. Mechanisms of antimicrobial peptide resistance in Gram-negative bacteria. Antibiotics 4: 18-41.

3. Chen LW, Kao PH, Fu YS, Lin SR, Chang LS. 2011. Membrane-damaging activity of Taiwan cobra cardiotoxin 3 is responsible for its bactericidal activity. Toxicon. 58: 46-53.

4. Curcio-Vonlanthen V, Schneider CH, Frutig K, Blaser K, Kalbacher H. 1997. Molecular parameters in melittin immunogenicity. J. Pept. Sci. 3: 267-776.

5. Guina T, Eugene CY, Wang H, Hackett M, Miller SI. 2000. A PhoP-regulated outer membrane protease of Salmonella enterica serovar Typhimurium promotes resistance to alpha-helical antimicrobial peptides. J. Bacteriol. 182: 4077-4086.

6. Ha YJ, Kim SW, Lee CW, Bae CH, Yeo JH, Kim IS, Gal SW, Hur J, Jung HK, Kim MJ, Bang WY. 2017. Anti-Salmonella Activity Modulation of Mastoparan V1-A Wasp Venom Toxin-Using Protease Inhibitors, and Its Efficient Production via an Escherichia coli Secretion System. Toxins (Basel). 9: 321.

7. Hetru C, Letellier L, Ziv O, Hoffmann JA, Yechiel S. 2000. Androctonin, a hydrophilic disulphide-bridged non-haemolytic anti-microbial peptide: A plausible mode of action. Biochem. J. 345: 653-664. 
8. Kim MH. 1996. Bee venom therapy and bee venom herbal acupuncture therapy. Seoul: Korea Educational Planning. 20-37, 41-2, 57, 70, 72, 133-49, 171-176.

9. Koh MS. 1993. Collection on oriental medicine-oriental medicine of animal origin. Seoul: Yeogang Publisher. 185-190.

10. Kokot ZJ, Matysiak J. 2009. Simultaneous determination of major constituents of honeybee venom by LC-DAD. Chromatographia. 69: 1401-1405.

11. Kwan DH, Lee JD, Choi DY. 2011. The study of anticancer effects of bee venom for aqua-acupuncture. The Acupuncture. 18: $129-145$.

12. Lee JD. 2000. Bee-venom theraphy: method of clinical approach. Journal of Korean Medicine. 21: 3-8.

13. Lee JS, Kwon GR, Lee SB. 2000. A study on major components of bee venom using electrophoresis. Journal of Pharmacopuncture. $3: 153-168$.

14. Leandro LF, Mendes CA, Casemiro LA, Vinholis AH, Cunha WR, de Almeida R, Martins CH. 2015. Antimicrobial activity of apitoxin, melittin and phospholipase $A_{2}$ of honey bee (Apis mellifera) venom against oral pathogens. An Acad Bras Cienc. 87: 147-155.

15. Machado RJA, Estrela AB, Nascimento AKL, Melo MMA, Torres-Rego M, Lima EO, Rocha HAO, Carvalho E, SilvaJunior AA, Fernandes-Pedrosa MF. 2016. Characterization of TistH, a multifunctional peptide from the scorpion Tityus stigmurus: Structure, cytotoxicity and antimicrobial activity. Toxicon 119: 362-370.

16. Nawrocki KL, Crispell EK, McBride SM. 2014. Antimicrobial peptide resistance mechanisms of gram-positive bacteria. Antibiotics 3: 461-492.

17. Oguiura N, Boni-Mitake M, Affonso R, Zhang G. 2011. In Vitro antibacterial and hemolytic activities of crotamine, a small basic myotoxin from rattlesnake Crotalus durissus. J. Antibiot. 64: 327-331.

18. Piek T. 1986. Venoms of the hymenoptera. London, United Kigdom : Academic press. 1-547.

19. Powers J-PS, Hancock REW. 2003. The relationship between peptide structure and antibacterial activity. Peptides 24: 16811691.

20. Ramirez-Carreto S, Jimenez-Vargas JM, Rivas-Santiago B, Corzo G, Possani LD, Becerril B, Ortiz E. 2015. Peptides from the scorpion Vaejovis punctatus with broad antimicrobial activity. Peptides 73: 51-59.

21. Rybak-Chmielewska H, Szczęsna T. 2004. HPLC study of chemical composition of honeybee (Apis mellifera L.) venom. Journal of Apicultural Science. 48: 103-109.

22. Wang K, Li Y, Xia Y, Liu C. 2016. Research on Peptide Toxinswith Antimicrobial Activities. Ann. Pharmacol. Pharm. 1: 1006. 